\title{
AFFECTING FACTORS OF THE PARTICIPATION OF VISUALLY IMPAIRED ATHLETES IN SPORTS WITHIN THE FRAMEWORK OF SOCIO-ECOLOGICAL THEORY
}

\author{
Dinçer Özdemir ${ }^{1}$, \\ Mehmet Şahin ${ }^{2 i}$, \\ Faruk Salih Şeker ${ }^{3}$ \\ ${ }^{1}$ MSc, Physical Education and Sport Sciences, \\ İstanbul Gedik University, \\ İstanbul, Turkey \\ ${ }^{2}$ Assoc. Prof., Faculty of Sport Sciences, \\ İstanbul Gedik University, \\ Istanbul, Turkey \\ ${ }^{3} \mathrm{PhD}$, Faculty of Sport Sciences, \\ İstanbul Gedik University, \\ İstanbul, Turkey
}

\begin{abstract}
:
The aim of the study is to determine to examine the current literature concerning the dynamics that encourage participation in sportive/physical activity in visually impaired individuals about the social ecological theory offered by developmental psychologist Uri Bronfenbrenner. This theory argues that the environmental layers have an effect on the development processes of individuals. Three separate systems constitute Bronfenbrenner's model. These are the microsystem, mesosystem and exo-system, while all of these systems can operate individually on the individual, they are also systems that can work together on the individual. The microsystem constitutes the smallest and closest environment the individual lives. In the microsystem, such as parents, friends, staff (coach, teacher, club president), school, form the micro-system layer. On the other hand, the mesosystem consists of the interactions of different microsystems of which the individual is a part. In other words, it is basically a whole consisting of different microsystems. For example, it includes the relations between an individual's home and school, peer group and family and other social institutions. The exo -system layer covers the social structures that make up the institutional impact and the variables that show the interaction with these structures, such as institutional support, legal regulations, financial support, guidance service, management and auditing. In the study, we used qualitative analysis methods and techniques. We preferred the "purposive sampling" in determining the sample group in the study. We collected data from 13 male and 1 female impaired active athletes participated in the research and the ages of these participants
\end{abstract}

i Correspondence: email cumsahin@hotmail.com 
were in the range of 17-47 years, living in Istanbul, Turkey. We used semi-structured, open-ended questions with the thematic analysis method of data. We took notes, kept diaries and recorded all impressions with dates and times. The results of the research evidently layout that all the variables that visually impaired individuals interact throughout their lives have an impact on their participation in sports. In this context, individual well-being, family characteristics, the nature of the relationship with the geographical features of the region and adaptation to the age individuals lived showed that all the variables were in a relationship with each other like the links of the chain.

Keywords: visually impaired people, participation in sports, socio-ecological theory

\section{Introduction}

The amount of visually impaired people in the world has been increasing dramatically day by day. The World Health Organization (WHO) stated that the need for eye care in the global context has increased rapidly over the years and it emphasizes that it will pose a significant challenge for health systems in the future. WHO published a world vision report and said that health systems for the visually impaired individuals and other disabled people to be strengthened. The world vision report conveyed that there may be at least 2.2 billion visually impaired people in the world (the world report on vision, 2019). According to the February 20121 data of the Ministry of Family, Labor and Social Services in Turkey, the number of visually impaired people registered in the data system is 215,076 . Their ratio compared to other disabled people is 9.53 . These figures show a very high representation in the total population.

Visually impaired individuals' the healthy life depends on their being in social interactions. One of the most important means of connecting these individuals to social life will be to involve them in sports activities. In spite of the fact that plenty of benefits of sports activities, the productive benefits of sports activities participation rate of visually impaired individuals in Turkey is quite low.

The studies conducted in previous years have shown that the physical and mental health status of individuals is higher than those with visual impairments. The quality of life of visually impaired individuals declines due to both inactivity and disability because of aging. For this reason, the involvement of these individuals in daily activities will decrease over time. Especially the lack of motivation of the disabled makes it difficult for these individuals to participate in sports activities (Jaarsma et al., 2014). Thus, it is necessary to provide the necessary support against possible difficulties to facilitate the participation of these individuals in sports activities.

Inevitably, a person finds himself from firstly home to later in a different social organization such as a school, a community and a cultural socio-ecological environment. Each of these systems unsurprisingly interacts with each other and with the person's life. Consequently, it is very important to govern the factors affecting participation in sports in visually impaired people from their point of view in terms of socio-ecological theory. 
Visual impairment was first defined by the World Health Organization (WHO) in 1978. This disorder is classified as low vision and completely blind in Version 9 of the International Classification of Diseases (ICD-9). In the following years, WHO made reclassification the term. According to the classification (ICD-10), the ratio of low vision to visual acuity of the best eye was defined as less than 20/60 but equal to or better than 20/400. And the low vision was defined in two different categories as moderate and severe low vision (Atasavun, 2004, Atasavun et al., 2010, Atasavun, Uysal, Düger, 2012). The individual's capability to use basic human rights is possible by completing cognitive, emotional, and psychomotor development in the field of education. One of the most important general objectives of education is to indisputably enable the individual to have a role in accordance with his/her self in society by improving his/her abilities and skills. However, the physical feature of visually impaired individuals is a major impediment to the use of fundamental human rights. In this regard, physical activity plays an important role in keeping the body against diseases and in reaching the upper capacity of the respiratory and circulatory systems. It is a very crucial factor in maintaining the physical capacity of the individual, restricting postural disorders, reducing nervous tensions and preventing heart diseases. In addition, it is very imperative for the healthy functioning of the joint tissues connected to the muscles of the individuals. Besides, physical activity plays an effective role in regulating the individual's social activities and getting rid of loneliness (Arabac1 et al, 2007).

In his book "The Ecology of Human", Bronfenbrenner (1976) clarified the effect of the environment with which he is in contact on the development of the personality of the individual. Bronfenbrenner's theory allowed us make sense of the events and perspectives of individuals with vision problems. In this way, it helped us learn about the processes that affect the participation processes of visually impaired individuals in physical activity, and the practices and what needs to be done to improve these processes.

It is a scientifically realistic approach that the personal characteristics of individuals, family characteristics, environmental factors and institutional factors are very important in the development of the individual. Improvement of these variables is only possible if the individual is in a state of well-being. This recovery can only depend on the individuals with whom the individual interacts.

\section{General Information}

\subsection{Disability and Visual Impairment}

The World Health Organization (WHO) defines disability as the limitation or inability to fulfill the functions expected from the person depending on the disorder, age, gender, social and cultural factors. The Turkish Government enacted the Disability Law in 2005. This law stresses that a disabled person is defined as a person who has lost his physical, mental, spiritual, emotional, or social skills in various degrees as a result of congenital or subsequent illness or accident, cannot comply with the requirements of normal life, or has difficulty in meeting his needs. However, these individuals receive support such as 
protection, care, rehabilitation, counseling (Disabled People's Law and Related Legislation, 2008).

\subsection{Motor Development Features}

While the developmental processes of individuals vary from person to person, they are also in continuity. The visual sense of individuals is considered as the most important input in the motor development processes of individuals. Sometimes there may be delays and sometimes differences depending on the amount of disability in terms of depending on the development of the individual. (Demir, T., \& Ülker, Ş. E. N., 2009). The development of basic motor skills (locomotor, object control) in the developmental processes of individuals allows them to use their potential better (Haegele and Porretta, 2015), to develop their personality, to participate in physical activity (Hands \& Larkin, 2006, Hands, 2008), to increase his physical fitness (Haegele \& Porretta, 2015). Porretta, 2015) to contribute to individuals becoming aware of their body (Strickling \& Pogrund, 2002).

It is unfortunate that it has been frequently seen loose musculature, foot deformation and spinal curvature in visually impaired people due to posture and gait disturbances. At the same time, these individuals walk by dragging their feet. For this reason, the heads and abdomens of these people are prominent. As a result, with the participation of the visually impaired in sports activities, participation in sports activities will help to eliminate the inevitable fear of being harmed by the environment due to vision loss (Özer, D., 2001).

\subsection{Physical Activity and Sports for the Visually Impaired}

The disabled individuals' regular activities can prevent musculoskeletal problems that may develop due to inactivity. At the same time, physical activity and sports provide important contributions to individuals' ability to live independently (THSK, 2015b).

Visually impaired individuals should be encouraged to involve in physical activity for at least 10 minutes a day. In the following periods, the activity time should be increased gradually and ultimately, these people should do at least an average of 60 minutes per day. The participants must continue the program within a certain period and ensure continuity in participation. Visually impaired people carry on the physical activity program in order to reduce their involuntary movements, from time to time the intensity and duration of these activities can be increased according to the need. Especially visually impaired individuals should prefer team sports to contribute to their socialization skills. However, the individuals should warm- up and cool down before and after physical activity to prevent injuries (THSK, 2015c).

\subsection{Socio-Ecological Approach}

Many research results have shown that lots of scientific studies have contributed to an accurate understanding of the developmental process of human beings. The researchers have conveyed important information to us with various perspectives and the theories 
they have developed. The results of the research have focused on the developmental process of the human species, and especially with the emergence of different models, it has enabled us to obtain practical data about the development process of human beings. Mainly, Urie Bronfenbrenner's socio-ecological approach occupies an important place in behavioral environment theories. His theory emphasizes the attempt to understand a child's individual development in the context of their multiple environments, also known as ecological systems.

In 1976, Bronfenbrenner settled his socio-ecological perspective in line with his philosophical views. The ecological model tries to explain that we make contact with various environments throughout our time of life that may have an effect on our behavior in varying degrees. Bronfenbrenner's ecological model sought to reveal the internal and external factors in the development of any individual. Bronfenbrenner (1976) emphasized that individuals are born and raised in a social and cultural system. In conformity with the theory states that each social and cultural environment affects another social and cultural environment. That is, the individual is born into his social norms, culture, history, values and rules of a particular family. Family members are always in contact with other families, schools, communities, and other institutions. As a result, all this physical and social environment has a great impact on the child's family, and then on the child.

\section{Material and Methods}

This study tried to reveal the perceptions of visually impaired individuals in their interaction with the environment they live in during their participation in sports.

We used the thematic analysis method, which is a qualitative data analysis method, in order to identify the patterns in terms of the meaning of the data set we collected from the interviews with the participants in the research. The data were analyzed according to thematic coding about the theoretical framework.

In the study, the factors affecting the participation process of visually impaired individuals in sports consisted of 4 variables, namely individual characteristics, familial characteristics, environmental characteristics and institutional characteristics.

The first variable of the study was the individual effect variable. The content of this variable included self-confidence, sociability, self-actualization, physical development, effort, individual desire, financial situation, mental development, individual experience, self-discipline, independence, commitment to life, and transportation. Another variable was the familial effect. This included family support, family anxiety, family acceptance of the child, and family awareness. Another variable was environmental impact. The friend support, community awareness, environmental support, appreciation and prejudice were included in the environmental impact variable. Institutional impact variation included institutional support, legal regulations, facilities, financial support, personnel support, materials, management and supervision, guidance service and corporate awareness. 
We collected the data by using the phone interview method in the research. The COVID-19 pandemic conditions forced us to choose the phone interview method. We determined the order and style of the questions in the interview. We asked the participants the same question in the same order. The questions in the interview consisted of standardized open-ended questions (Büyüköztürk et al., 2013).

Table 1: Demographic profile

\begin{tabular}{|l|c|c|c|c|c|c|}
\hline & Age & Gender & $\begin{array}{c}\text { Brother or } \\
\text { sister number }\end{array}$ & $\begin{array}{c}\text { Education background } \\
\text { / Occupation }\end{array}$ & $\begin{array}{c}\text { Causes of } \\
\text { disability }\end{array}$ & $\begin{array}{c}\text { Ratio of } \\
\text { disability }\end{array}$ \\
\hline K1 & 47 & M & 3 & Employee / PhD & congenital & $90 \%$ \\
\hline K2 & 47 & M & 9 & Retired / univ. student & congenital & $90 \%$ \\
\hline K3 & 17 & M & 2 & high school student & congenital & $71 \%$ \\
\hline K4 & 17 & M & 3 & high school student & congenital & $60 \%$ \\
\hline K5 & 17 & M & 4 & high school student & congenital & $70 \%$ \\
\hline K6 & 36 & M & 4 & employee & congenital & $90 \%$ \\
\hline K7 & 21 & M & 3 & bachelor's degree & congenital & $90 \%$ \\
\hline K8 & 33 & M & 2 & employee & congenital & $97 \%$ \\
\hline K9 & 31 & M & 3 & bachelor's degree & by accident & $90 \%$ \\
\hline K10 & 47 & F & 4 & $\begin{array}{c}\text { employee / } \\
\text { bachelor's degree }\end{array}$ & congenital & $90 \%$ \\
\hline K11 & 24 & M & 2 & $\begin{array}{c}\text { employee } \\
\text { employee / } \\
\text { high school }\end{array}$ & by accident & $90 \%$ \\
\hline K12 & 31 & M & 2 & congenital & $100 \%$ \\
\hline K13 & 29 & M & 3 & employee & congenital & $97 \%$ \\
\hline K14 & 30 & M & 2 & congenital & $90 \%$ \\
\hline
\end{tabular}

The table includes information about the demographic characteristics of the participants. To determine the sample group of the research, we made contact with visually impaired sports clubs over the internet. We then were in communication with "13 men and one female" who were actively involved in sports on a regular basis. Our main goal was to focus on particular characteristics of the population that were of interest, which would best enable us to answer our research questions. So that we used the purposive sampling method to determine the sample group.

13 male and one female each actively sustaining their sports life visually impaired participated in the research. They were living in Istanbul. The ages of the participants were in the range of 17-47 years. Besides, the nine participants were born with visual impairment, and the five participants were accidental. Furthermore, the rate of vision loss of the participants was between $97 \%$ and $60 \%$. While the six participants were actively working, the four participants were students and one participant was retired. Meanwhile, one participant had a doctorate degree; the six participants were undergraduates and finally the four participants were continuing their education. 


\section{Results and Discussion}

This study applied the socioecological framework of Bronfenbrenner's theory to identify the factors that influence visually impaired individuals' participation in sportive activities. In line with the theory of Bronfenbrenner findings from this study showed that individual, familial, environmental and institutional factors entirely affected visually impaired individuals' participation in sportive activities.

Through the review of the transcripts, the researchers examined the factors affecting the participation of visually impaired individuals in sports activities according to the socioecological theory of Bronfenbrenner.

Findings from each level of the model are discussed. The results of the previous studies were consistent with the results of our study on the positive relationship between sports and self-confidence. Çalışkan's (2004) study with visually impaired individuals emphasized the contribution of individuals to self-confidence through their participation in sports. In addition, Hutzter and Bar-Eli (1993) examined the effects of sports on individuals with disabilities. The results of the study showed that physical activities within scientific limits had a positive effect on self-confidence and self-esteem in these individuals. Valliant, et al. (1985) reported that athletes with disabilities had significantly higher self-esteem than athletes without disabilities.

The factor of being social is one of the factors that show the perception levels of the participants at the highest rate among the individual effect variable. The visually impaired individuals who participated in the study stated that their performance in socialization increased with participation in sports.

The impaired individuals in the research stated that the success of the participants in their own sports branches was a factor that motivates them. As a result of the research, sports activities have fulfilled its function as the most important instrument in the process of self-fulfillment realization and self-transformation of individuals. Participants noted that sports increased their motivation to fight and eventually they became successful.

One of the important factors of the ecological environment model is physical fitness. The results of the research specified that visually impaired individuals made positive physical progress after they participated in sports.

Many studies confirm that the willingness to exert effort to achieve an action should be acquired from early childhood. The results of the research confirmed that the difficulties faced by the participants with their participation in sports activities were perceived as small and insignificant by them. They also said that they were determined to tackle the obstacles that might come their way.

The desire to start a sportive activity is the most important step of participation in sporting activities. The individuals participating in the research emphasized that they thought that sports activities were a means of being firmly attached to life.

Bundon et al. (2018) said that financial concerns about Paralympic athletes' struggle to maintain sports forcing some athletes to leave sports earlier. This shows how 
effective the financial situation is in participation in sports for individuals with disabilities.

One of the important factors of the individual effect variable in social ecology theory was mental development. The research results supported that mental development was a fundamental element of personality development. İlhan's work in 2009 with the parents of children with special needs confirmed our work results. The study showed that the parents of individuals with special needs stated that sports activities had a positive effect on their children's mental and all other developmental areas.

Every planned activity principally aims to make the individual independent. The research results showed that the factor of independence increased with the participation of these individuals in sports activities. The outcomes of the study conducted by İlhan et al. (2015) showed similarity with our study. The study of İlhan and others supported that the children participating in the athletics program improved and became independent in the areas of self-care and daily living skills.

Our research results confirmed that visually impaired individuals made improvement in having a more positive outlook on life. The studies of Kumcagiz and Çayir (2018) are in harmony with our study. This study stated that the perspectives of physically disabled individuals participating in sports activities changed positively, and they were looking forward to the future with more planned and with hope. Groff et al. (2009) also stressed that participation in adapted sports increased the quality of life of individuals with cerebral palsy.

Family support is one of the main factors of the familial effect variable, which is estimated from the socio-ecological theory perspective in the participation of visually impaired individuals in sports activities. Caliskan et al. (2008) obtained results in their research titled "Opinions of families with disabled children about physical education and sports activities", in which $93.9 \%$ of families would show success in the participation of disabled people in sports activities. Kaur (2010) indicated that a supportive family environment could help these individuals develop self-confidence and self-esteem. In this context, the results of our study supported that family support was very important in the participation of visually impaired individuals in sports activities.

The ability of individuals with special needs to acquire independent living skills is the greatest gain that these individuals can acquire during their life. Sports offer people an approach that requires independence by nature. Therefore, parents should give up their overprotective approach to their children and prefer to help these individuals' exhibit independent behaviors.

Adaptation and acceptance are the most constructive effects on people with disabilities. Kandel and Merrick (2007) stated that beyond perceiving families as helpless victims during the admissions process, they should have been perceived as institutional structures that help individuals adapt to the structuring process.

The results of our study showed that the family support factor had a domineering place in the participation of visually impaired individuals in sports activities. Willis et al. 
(2019) emphasized in their study that family support-centered approaches can increase participation in physical activity for children and youth with disabilities. In this context, parents will be able to give more support to their children by getting to know their children with disabilities better.

The visually impaired individuals perceived the environmental impact variable as an important facilitating factor in their participation in sports activities from the perspective of socio-ecological theory. Shields et al. (2012) similarly, disabled individuals expressed peer participation and support as a facilitating factor in their participation in physical activity. The majority of our study participants emphasized the support of friends in participating in sports activities.

The visually impaired individuals participating in the research believe that their participation in sports activities is a very important factor in raising the awareness of society. Zoerink's (1992) study emphasized the importance of doing regular physical activity and expressed the difficulties faced by families with disabled children due to the different perspectives of society. In another study by Akyol and İlkim (2018), it was stated that the participation in sports activities can help overcome the negative perception in the society. Undoubtedly, sports is one of the most important activities in raising awareness in society.

The results of our research confirm how important was environmental factors to support in the individuals participation in sports activities. In a similar study, Shields et al. (2012) revealed that environmental barriers and facilitators much affected the quality of sports activities of children with disabilities.

Appreciation from the environment affects success positively. Our study has proven this idea to be true. In the study of Mauerberg-deCastro et al. (2016), they stated that exercise programs contribute positively to the health of individuals with disabilities, however, these individuals mostly expect appreciation and personal approval in their sports activities.

It is a known fact that ascriptions about athletes such as a general "perfect body" or "efficient body" lead to negative motivation on disabled individuals. MauerbergdeCastro et al. (2016) identified that paralympic athletes suffer from such biased generalizations. The statements of our participants in our study were also consistent with the findings of these studies.

The institutional support factor of the institutional effect, which was another variable of our research, showed that visually impaired individuals played an active role in participating in sports activities. In his study (2015), Trevedios emphasized that the athletes should ask local companies to sign sponsorship contracts and that companies should provide sponsorship support to the athletes as well as investing in their companies. Some individuals participating in the research stated that they received more or less institutional support for their participation in sports. The more the institutional sponsorship support granted to the visually impaired individuals, the more the participation and continuation of the individuals in the sportive activities would increase. 
The study revealed that facility support was another important factor for individuals to take part in sports activities. Akyol and İlkim (2018) also stated the importance of facility support in their study. They highlighted that it was necessary for individuals with autism and physical disabilities needed to participate in sports at a sufficient level. In another research result, Charles and Chinaza (2018) indicated that the lack of facilities was one of the barriers for disabled individuals to participate in physical activity.

The participants in the study emphasized that they would have difficulties in continuing their sportive activities without financial support. In their study, MauerbergdeCastro et al. (2016) revealed that financial support was very important in sustaining the sports activities of disabled athletes. In 2013, they noted that the Brazilian Paralympic Committee launched the "Heroes of disability sports" program, and athletes with disabilities received a 12-month financial grant. It shows how important it is for disabled individuals to receive financial support.

Another research result indicated that the presence of the personnel providing guidance services to the visually impaired athletes had a significant effect on the participation of disabled individuals in sports activities. Charles and Chinaza (2018) stressed that the absence of physical activity specialists had been a very important difficulty for visually and hearing-impaired individuals to participate in sports.

Disabled individuals involved in sportive activities perceived their inability to have sufficient materials as an important obstacle for these athletes. Charles and Chinaza (2018) clarified that the participation of individuals with disabilities in sports activities was affected by various impediments and facilitators specific to their environment. According to the findings of their studies, one of the obstacles was the lack of physical activity insufficient number and variety of materials or inadequacy.

\section{Recommendations}

The effects of sports activities on the participants depend on the harmony of the management and supervision of sports facilities. Individuals participating in the research perceived deficiencies and disruptions in functioning as obstacles to participation in sports.

One of the ways to change attitudes is to inform the people. This is possible through education and guidance services. Visually impaired individuals have made suggestions to the managers of the institutions where they do sports. The most important part of their recommendations was that institutions should have an awareness about disabled athletes.

The prominence of environmental effect was obvious in shaping the experiences of participating in sports activities of the visually impaired individuals.

It is very important for visually impaired individuals involved in sports activities to share their experiences with individuals in the same situation as themselves. They should explain what they will gain from doing sports. At the same time, they should emphasize that they should make enough effort in the process of participating in sports 
and that these individuals can strengthen themselves and that they will contribute to the internal processes of being themselves by sticking to life.

The results of the familial impact variable show that families should act consciously while raising disabled individuals, and they should also create opportunities for their children to act independently while fulfilling their children's needs. In other words, it is possible by raising awareness of families and society in terms of sociological, psychological and pedagogical aspects. The main task of the institutional structure is to raise the awareness of society. Institutions should include sponsorship activities in public awareness activities.

The factors affecting the participation processes of the visually impaired in sports should be investigated socio-ecologically and analyzed in different provinces. The results should be compared with each other.

The factors affecting the participation processes of the visually impaired in sports should be examined with sedentary participants from a socio-ecological point of view and analyzed in comparison with our research.

Although the study offers valuable contributions, the limitation of the research was that we had to collect data through telephone interviews because of the pandemic conditions.

\section{Conclusion}

This qualitative study contributes to the fields of visually impaired individuals by socialecological theory the factors that influence visually impaired individuals in sports activities.

The contribution of socio-ecological factors is very important in the participation of visually impaired individuals in sports activities. Supporting these factors will increase the participation of visually impaired individuals in sports and ultimately create healthier and happier individuals. The individual characteristics of the people, family support, support of the environment and institutions are essential for successful participation in sports. Apparently, Bronfenbrenner's theory provided a framework for visually impaired people or their parents and friends to form effective relationships with them and surround them in a positive environment. Positive relationships and a conducive environment will enable visually impaired individuals to achieve the highest possible success.

\section{Acknowledgements}

We wish to express our gratitude to the participants who volunteered for this study.

\section{Conflict of Interest statement}

The authors declare that they have no conflict of interest related to the study or preparation of the manuscript. 


\begin{abstract}
About the Authors
Dinçer Özdemir has a master's degree from Istanbul Gedik University and her main interest is special education and sports.
\end{abstract}

Mehmet Şahin is presently Assoc. Prof. in the Faculty of Sport Sciences at Istanbul Gedik University. His research interests include philosophy of sports, history, and sports and also psychosocial issues the sports education.

Dr. Faruk Salih Şeker currently works at Istanbul Gedik University. His main current research interest lies in the area relationship between special education and sports.

\title{
References
}

Akyol, B., \& İlkim, M. (2018). Socialization of disabled people with sports activities and their problem encountered in participating in sports activities. Türk Spor ve Egzersiz Dergisi, 20(2), 100-104.

Arabac1, R., \& Çankaya, C. (2007). Beden eğitimi öğretmenlerinin fiziksel aktivite düzeylerinin araştırılması. Uludağ Üniversitesi Ĕ̆itim Fakültesi Dergisi, 20(1), 1-15.

Atasavun Uysal, D. Düger, T. (2012). Visual Percepton training on social skills and activity performance in lowvision children. Scand J Occup Ther, 19:33-41

Atasavun Uysal, S. Erden, Z. Albayrak, T. Demirtürk, F. (2010). Comparison of Balance and gait in vissualy or hearing impaired children. Percept mot skills, 111(1), 71-80

Atasavun, S. (2004). Farklı görme düzeylerine sahip çocuklarda motor ve kognitif yeteneklerinin karşılaştırılması. (Master's Thesis). Hacettepe Üniversitesi, Ankara. Bakanlığı, S. (2014). Türkiye fiziksel aktivite rehberi. Türkiye Halk Să̆hı̆̆ı Kurumu, Ankara. Başkanlığı, T. B. Ö. İ. (2008). Özürlüler Kanunu ve İlgili Mevzuat, 3. Baskı. Ankara: TC Başbakanlık Özürlüler İdaresi Başkanlı̆̆ı Yayınları.

Bundon, A., Ashfield, A., Smith, B., \& Goosey-Tolfrey, V. L. (2018). Struggling to stay and struggling to leave: The experiences of elite para-athletes at the end of their sport careers. Psychology of Sport and Exercise, 37, 296-305.

Büyüköztürk, Ş., K1lıç Çakmak, E., Akgün, Ö.E., Karadeniz, Ş., Demirel, F., 2013. Pegem Eğitimde Bilimsel Araştırma Yöntemleri - Şener Büyüköztürk Pegem Akademi Yayıncılık

Çalışkan, E., Şirinkan, A., Erciş, S., Saraçoğlu, N. ve Akoğuz, N. (2008). Engelli Çocuğu Olan Ailelerin Beden Eğitimi Ve Spor Etkinlikleri Hakkındaki Görüşleri, 10. Uluslararası Spor Bilimleri Kongresi Poster Bildiri Uzun Özetleri Kitabı. Abant İzzet Baysal Üniversitesi, Bolu.

Charles, O. O., \& Chinaza, N. K. (2018). Barriers and Facilitators of Physical Activity Participation Among Youth with Visual and Hearing Impairments in Nigeria: A Qualitative Study. Palaestra, 32(3).

Demir, T., \& Ülker, Ş. E. N. (2009). Görme Engelli Öğrencilerin Çeşitli Değişkenler Açisindan Öğrenme Stilleri Üzerine Bir Araştirma. Journal of International Social Research, 2(8). 


\begin{tabular}{lllll}
\hline Engelli ve & Yaşlı & İstatistik
\end{tabular}
https://www.ailevecalisma.gov.tr/media/73073/eyhgm istatistik bulteni subat20 21.pdf

Groff, D. G., Lundberg, N. R., \& Zabriskie, R. B. (2009). Influence of adapted sport on quality of life: Perceptions of athletes with cerebral palsy. Disability and rehabilitation, 31(4), 318-326.

Haegele, J. A., \& Porretta, D. L. (2015). Physical activity and school-aged individuals with visual impairments: A literature review. Adapted Physical Activity Quarterly, 32(1), 68-82.

Hands, B., \& Larkin, D. (2006). Physical fitness differences in children with and without motor learning difficulties. European Journal of Special Needs Education, 21(4), 447-456.

Hutzter, Y., \& Bar-Eli, M. (1993). Psychological benefits of sports for disabled people: A review. Scandinavian Journal of Medicine \& Science in Sports, 3(4), 217-228

İlhan, L. (2009). Zihinsel Engelli Çocuğu Olan Anne-Babalarin Çocuklarinin Özel Eğitimleri Sürecinde Beden Eğitimi ve Spor Etkinliklerine Yaklaşimlarinin Değerlendirilmesi. Beden Eğitimi ve Spor Bilimleri Dergisi, 3(1), 38-48.

Jaarsma et al. (2014). Barriers to and Facilitators of Sports Participation in People with Visual Impairments, Adapted Physical Activity Quarterly, (31) 240-264 264 http://dx.doi.org/10.1123/apaq.2013-0119.

Kandel, I., \& Merrick, J. (2007). The child with a disability: parental acceptance, management and coping. The scientific world Journal, 7, 1799-1809.

Kaur, Y. (2010). Family support model for the management of disabled children. Studies on Home and Community Science, 4(3), 179-184.

Kumcağız, H., \& Çayır, G. A. (2018). Sporun, fiziksel engelli bireylerin yaşam kalitesi üzerine etkisine ilişkin görüşler. İnönü Üniversitesi Ĕ̆itim Fakültesi Dergisi, 19(3), 654-669.

Mauerberg-deCastro, E., Campbell, D. F., \& Tavares, C. P. (2016). The global reality of the Paralympic Movement: Challenges and opportunities in disability sports. Motriz: Revista de Educação Física, 22(3), 111-123.

Özer DS. (2001) Engelliler için Beden Eğitimi ve Spor, 1. Basım, Ankara, Nobel Yayın Dağıtımı.

Shields, N., Synnot, A. J., \& Barr, M. (2012). Perceived barriers and facilitators to physical activity for children with disability: a systematic review. British journal of sports medicine, 46(14), 989-997.

Strickling, C. A., \& Pogrund, R. L. (2002). Motor focus: Promoting movement experiences and motor development. In R. L. Pogrund \& D. L. Fazzi (Eds.), Early focus: Working with young children who are blind or visually impaired and their families (2nd ed., pp. 287-325). New York: American Foundation for the Blind.

The World Report on Vision (2019), https://www.iapb.org/learn/resources/the-worldreport-on-vision/ 
U. Bronfen Brenner (1976). The Ecology of Human Development. Experiments By Nature and Design. Harvard Universty Press, Cambridge, Massachussetts, London, England.

Valliant, P. M., Bezzubyk, I., Daley, L., \& Asu, M. E. (1985). Psychological impact of sport on disabled athletes. Psychological reports, 56(3), 923-929.

Willis, C. E., Reid, S., Elliott, C., Nyquist, A., Jahnsen, R., Rosenberg, M., \& Girdler, S. (2019). 'It's important that we learn too': empowering parents to

World Health Organization (WHO) (2014-2019, 2013a,2015a). Universal Eye Health: A Global Action Plan, Geneva, WHO.

Zoerink, D. A. (1992). Exploring sport socialization environments of persons with orthopedic disabilities. Palaestra, 8(3), 38-45.

Creative Commons licensing terms

Authors will retain the copyright of their published articles agreeing that a Creative Commons Attribution 4.0 International License (CC BY 4.0) terms will be applied to their work. Under the terms of this license, no permission is required from the author(s) or publisher for members of the community to copy, distribute, transmit or adapt the article content, providing a proper, prominent and unambiguous attribution to the authors in a manner that makes clear that the materials are being reused under permission of a Creative Commons License. Views, opinions and conclusions expressed in this research article are views, opinions and conclusions of the author(s). Open Access Publishing Group and European Journal of Special Education Research shall not be responsible or answerable for any loss, damage or liability caused in relation to/arising out of conflict of interests, copyright violations and inappropriate or inaccurate use of any kind content related or integrated on the research work. All the published works are meeting the Open Access Publishing requirements and can be freely accessed, shared, modified, distributed and used in educational, commercial and non-commercial purposes under a Creative Commons Attribution 4.0 International License (CC BY 4.0). 